The above results indicate to a certain extent that when the Brix readings of the cell-sap is between $1 \cdot 338$ and $1 \cdot 346$, the species concerned are likely to remain susceptible; and when the readings were 1.351 or above, the species were less susceptible or resistant. It is thus likely that the presence of excess soluble solids in the cell-sap of the leaves of the wild species of Sesamum renders it less liable to Antigastra attack. Further work on these lines is in progress.

Division of Entomology,

S. MukferJI

Indian Agricultural Research Institute, New Delhi.

'Ramanujam, S., Curr. Sci., 11, 426 (1942).

${ }^{2}$ Ramanujam, S., Curr. Sci., 13, 40 (1944).

s Yamasaki, M., and Arikado, H., Proc. 6th Int. Soc. Sugar Cane Tech., 475 (1938).

\section{Occurrence of Botrytis Fabæ Sardina in England}

THE Chocolate Spot disease of broad and field beans is well known and widespread throughout Great Britain, and causes considerable loss of crop when there is high humidity and much rain at the time of flowering. The cause of the disease, in the eastern counties at. least, was shown by A. R. Wilson $^{1}$, in 1937, to be the common fungus Botrytis cinerea Fr. He proved, however, that similar symptoms could be brought about by other Botrytis species, such as $B$. Tulipo Lind.

We have now shown that in the south-west of England, Chocolate Spot is caused mainly by Botrytis Faboe Sardiña. This fungus was described from Spain by Sardiña ${ }^{2}$ in 1929, and has been recorded also from Morocco, Cyprus, Egypt and China. It is readily distinguished from $B$. cinerea by its larger spores and smaller sclerotia. Our identification has been confirmed by Dr. P. H. Gregory.

National Agricultural Advisory Service,

L. OGilvie

M. MunRo

Bracken Hill,

Leigh Woods,

Bristol 8.

May 5.

'Wilson, A. R., Ann. Appl. Biol., 24, 258 (1937).

¿Sardiña, J. R., Mem. Soc. esp. Hist. nat., 15, 291 (1929).

\section{Speciation in Cichlid Fishes of East African Lakes}

Prof. C. Kosswig has suggested ${ }^{1}$ that factors which may contribute to the high evolutionary response of Cichlid fishes to the environments of the Great African Lakes are selective mating and specialized breeding habits, including monogamy at least until one brood becomes independent. A beginning has been made in the study of a group of closely related species in Lake Nyasa, the Tilapia of the T. squamipinnis group ${ }^{2,3}$. Before 1939 these had been considered as a single species. Slight differences in pharyngeal dentition had been observed in the larger fishes among a score of specimens in the British Museum (Natural History); but these, and slight variations in proportions of head and mouth, had not been thought sufficient for the recognition of more than one species. Field-work during the fishery survey of 1939 revealed that there are in
Nyasa probably four closely related species, for some of which it is still convenient to us Chambo, Saka, Lidole and $T$. karongoe (the local name of which I do not know). These seem to be the Nyasa representatives of the T. galilcea group of the genus, but all resemble each other much more closely than any species outside the Lake. Females and nonbreeding males of all are silver-grey with nearly vertical black bars. In Chambo the male becomes pale blue as the testes ripen; in the other three, ripe males are black. The four species (if they are species) cannot yet be recognized at all stages, but Lidole and Chambo can be distinguished from each other at a total length of $26 \mathrm{~cm}$. and more, and it is to these two that the following remarks apply.

The morphological differences between them are that Lidole has a more slender and more feebly toothed lower pharyngeal bone, usually a larger head and a larger mouth. The essential differences, that is, those that isolate them from each other, are : the breeding male of Lidole is black, that of Chambo is pale blue; the female of each shelters the young in her mouth, but only Chambo brings them into the reed-beds; Chambo ceases to shelter the young after they have reached a total length of $15 \mathrm{~mm}$., Lidole continues to shelter them in her mouth up to a length of $40 \mathrm{~mm}$. In addition there is evidence suggesting that Chambo inhabits a more inshore, Lidole a more offshore zone, although these zones overlap; and that the mating places are separate, that of Lidole being farther from shore than that of Chambo. Both species feed mainly on phytoplankton, and it would need a very extensive study to establish any average difference in the feeding habits. Presumably, however, Chambo has more opportunity to vary the plankton diet with periphytic Algæ or those of the bottom film, and the floating matter of the inshore water would include coarser organic debris than that of offshore water. The slight difference in dentition may be associated with these facts.

If it be assumed that the inshore habit is the more primitive, recent events show how the offshore habit may have been assumed. Since 1939, the level of Nyasa has risen, and in 1945 and 1946, when Miss R. Lowe went to Nyasaland to continue the Tilapia studies begun by my colleagues and myself in 1939 , the reed-beds, where it was customary to trap Chambo, and near which it was customary to seine them in the breeding season, were drowned, and the native fishing season was a failure. European fishermen, however, fished in open water with special gear and, I understand, caught Lidole, and one of the other species. It may have been such a change in lake-level that first gave rise to a race of Tilapia that managed to do without the reed-beds as nurseries for their young, sheltered them in the maternal mouth longer in compensation, and kept to the open water and a purely planktonic diet. A fall in lake. level could provide locally the conditions favourable to the evolution of a more inshore form from a specialized lacustrine form. This may perhaps account for the presence of the other two species, repeated fluctuations resulting in an alternating direction of the evolutionary process, with the fixation of partially converging forms oscupying overlapping ecological niches.

In these species, at least, it is only the female that has been found sheltering young in the mouth. The evidence points to a separation of the sexes during the period when the young are being sheltered. In the case of Chambo, males and females were caught 